IRSTI 06.51 .51

UDC 330

https://doi.org/10.46914/1562-2959-2021-1-3-80-87

\author{
I.V. ONYUSHEVA, *1 \\ $\mathrm{PhD}$, Associate Professor, \\ Professor of RAM, RANH. \\ *e-mail: dr.irina.onyusheva@gmail.com \\ K. LAOCHOCKCHAIKUL, ${ }^{2}$ \\ MBA. \\ e-mail: k.laochockchaikul@gmail.com \\ ${ }^{1}$ Turan University, Kazakhstan, Almaty \\ ${ }^{2}$ Stamford International University, \\ Thailand, Bangkok
}

\title{
ANALYZING FOREIGN MARKET ENTRY STRATEGIES: THE CASE OF WAL-MART'S ENTRY INTO THAILAND
}

\begin{abstract}
The paper is devoted to foreign market entry strategies, particularly, studying the case of the entry of the US company Wall-Mart - the world leader in wholesale and retail trade - into the Thailand market. In terms of globalization, many firms are trying to expand their business by entering foreign markets which determines the relevance of the study. That brings many social and economic benefits. However, the process is related with big risks which requires developing proper strategies for business success. In the research it is analyzed the external business environment, and causes why Wall-Mart has decided to enter the Thailand market, taking into account macroeconomic characteristics, growing domestic consumer demand, purchasing trend, as well as positive forecasts of sales growth in the overall retail sector. Moreover, the entry modes of Wal-Mart entering the Thai market are considered. It is performed the risk assessment and risk management strategies developed, accordingly. The importance for international businesses to conduct an in-depth external business environmental and risk analysis is proved before entering into other markets, as it provides insightful information about the features of the host country, its culture, knowledge of the local market and consumer needs, competitive business strategies and etc.
\end{abstract}

Key words: international business, foreign market, entry strategy, risk management, Wal-Mart, Thailand.

\section{Introduction}

The Wal-Mart Incorporation is an American based multinational retail corporation, headquartered in Bentonville, Arkansas. It is currently operating in 28 countries, with approximately 11,600 stores worldwide. 'Everyday low prices' strategy has helped Wal-Mart in achieving success on a global scale. Wal-Mart is continuously expanding chain of supermarkets, hypermarkets, discount-department, and grocery stores in different European and Asian markets. It is also operating e-commerce channels in almost 11 countries. It has successfully sustained retail and wholesale businesses in many countries outside the US, which include China, the United Kingdom, India, Canada, and Japan. However, its operations failed in Germany, Brazil, and South Korea [1].

\section{Main Provisions}

Main Provisions of the given article are based on the analysis of foreign market entry strategies conducted, particularly, studying the case of the entry of the US company Wall-Mart. Thus, it is reflected in the key research results divided in two parts: the country industry and entry mode analysis (US and Thailand), the external business environmental analysis and risk assessment and management plan, accordingly. 


\section{Materials and methods}

The research methodology of this paper is based on conducting the comparative analysis of existing patterns of macroeconomic development, political and social issues in the context of foreign market entry strategies, particularly the US and Thailand, considering the case of Wal-Mart entry into Thailand. It is implemented PESTEL analysis, defined the features of external business environment. Based on the PESTEL, the risk identification, risk assessment and risk management analysis conducted, as well as the causes and consequences analysis, and expert assessment.

The risk assessment, risk management and mitigation strategies have been developed based on indepth processing materials and respectful international research, macroeconomic and statistical data bases including Trade Economics, Reuters, World Bank, IMD and TMF group reports and etc.

\section{Results}

In this section it is included analysis of the US retail industry, analysis of entry modes and their motives and reasons. It is studied the features of external environment, and risk assessment and risk management, respectively.

Analyzing the US retail industry, the US retail chains comprising convenience stores, supermarkets, and hypermarkets are continuously expanding their global reach across the world. As per the 'Global Powers of Retailing' report in 2015, there are 76 largest retail corporations in the world that are based in the United States. Analysts estimate that the retail industry contributes two-third of GDP (gross domestic product) in the US economy. There are several retail giant leaders in the US retail industry, among which Wal-Mart is considered as one of the most valuable retail leaders. Other largest retail companies are Amazon, Target, The Kroger Co., J.C. Penny, and Costco, which shows that there is fierce competition in the domestic retail industry of the United States [2]. The overall U.S retail industry' success is also dependent on the online retail segment. As per analysts, total retail sales in the United States from the year 2012 to 2023 can be analyzed in the below graph (see Figure 1).

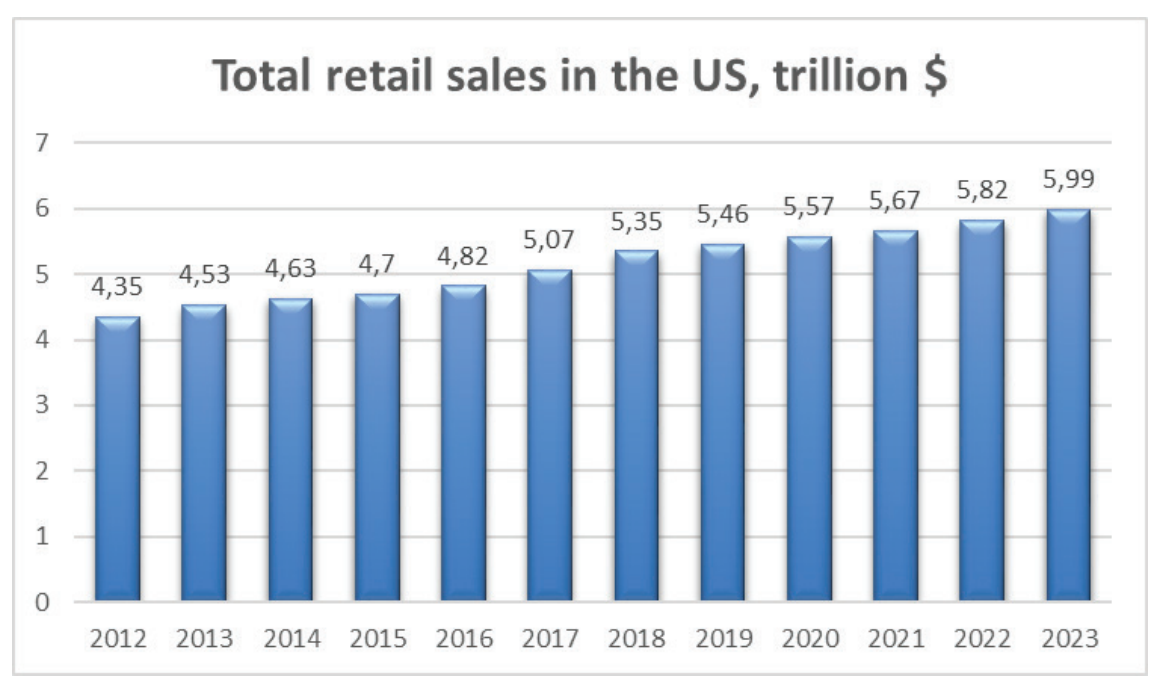

Figure 1 - Total retail sales in the US, trillion US\$, 2012-2023

Note - Source - Compiled on the base of [3].

The above statistics showed that total US retail sales have significantly increased to 5.46 trillion dollars in the year 2019 from 4.35 trillion dollars in the year 2012. Moreover, according to the analysts forecast, it is projected from the ongoing sales trend that retail sales can be further increased to 5.99 trillion dollars by 2023 [3]. It can be concluded that U.S retail companies can strengthen their international presence in upcoming years if they continue to meet consumer demands across the world by focusing on effective growth and expansion strategies. 
Regarding the motives for Wal-Mart to have the proposed international engagement, it should be mentioned several possible motives for Wal-Mart to have more international engagements. Firstly, WalMart is facing fierce competition from its competitors, and its growth process of internationalization is slower than other retail brands worldwide. Its competitors in the home country (Target Corporation and Costco) and in Germany (Aldi and Lidl) have started offering a wide range of products through digital channels, and they are continuously developing effective retail strategies to attract a broad range of customers. Online retailing is capturing share in the retail industry day by day, and companies are now using more online retail platforms to meet changing consumer needs. Although Wal-Mart has started partnering with digital brands like Jet.com and Bonobos to sustain competitive positioning, it is still facing tough competition in its home country because of Amazon's huge e-commerce platform for online retailing, which compels it to explore other growth opportunities that may include entering in new markets [4].

Secondly, ongoing trade wars and conflicts between the US and China are also impacting WalMart's overall retail sales as its revenue's one major portion comes from the Chinese region. WalMart's international-segment sale is declining over the past four to five years due to fierce competition and tensed international relations between countries. Analysts reported that Wal-Mart's international sales have dropped in third and fourth quarters by $2.3 \%$ in the year 2019 due to currency fluctuation and de-consolidation of operations in Brazil [4; p.12]. Wal-Mart's 'everyday low prices' and 'onestop-shop' strategies didn't work well in the Brazilian market, which led Wal-Mart to sell its $80 \%$ stake to private equity firm Advent International. However, this strategy worked well in the Indian market, which suggests Wal-Mart exploits other Asian markets by adopting a similar strategy. Thirdly, Wal-Mart can't further penetrate in its existing markets as it has already saturated most of its present markets domestically and internationally. All these factors can drive Wal-Mart to look for other markets that have high growth potential.

Speaking about reasons to enter Thailand, to fully exploit growth opportunities, Wal-Mart should opt for the Thailand market due to its high consumer purchasing power. In South-East Asia, Thailand is considered one of the most economically-stable countries. People in Thailand are inclined towards shopping at chain convenience stores, supermarkets, hypermarkets, and large scale shopping centers. An increasing number of tourists in Thailand are contributing a major part in the consumption of retail goods. Tourists' heavy expenditure on retail items has attracted many local and international retailers to invest in the Thai market. As per analysts, a significant rise in the number of supermarkets in Thailand was observed between 2015 (175) and 2018 (214) period. Currently, there are 14.4 thousand convenient stores [5].

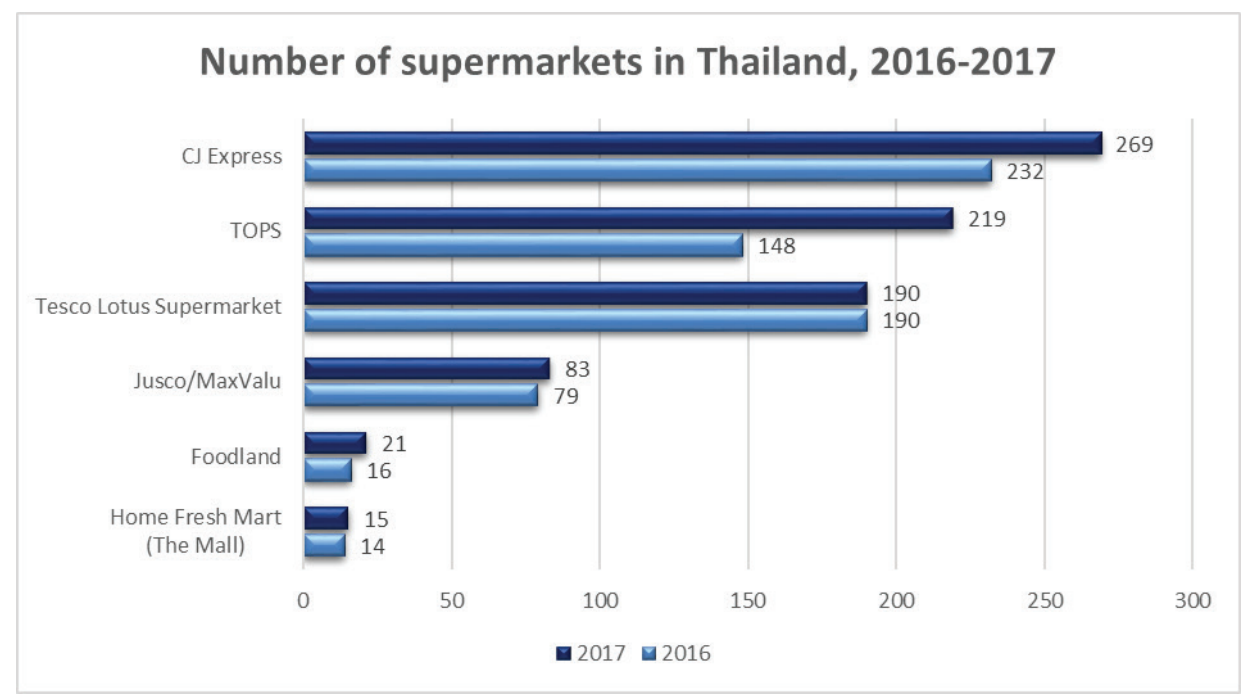

Figure 2 - Number of supermarkets in Thailand, 20162017

Note - Source - Compiled on the base of [5]. 
It is observed a significant rise in a number of supermarkets and hypermarkets in Thailand during 2016-2017, as depicted in the Figure 2 and Figure 3, accordingly:

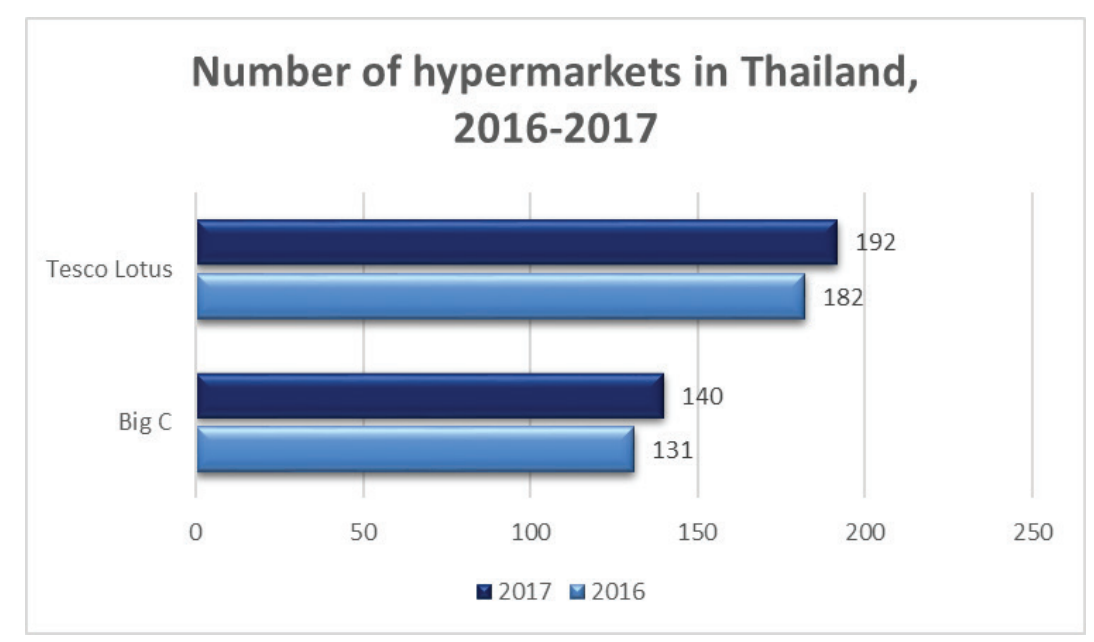

Figure 3 - Number of hypermarkets in Thailand, 2016-2017

Note - Source - Compiled on the base of [5].

From the graphs above, it can be concluded that there is an increasing demand of consumers for retail goods in Thailand due to which domestic and international retailers have continued to increase retail chains supermarkets and hypermarkets. This also shows that the Thai retail sector has fierce competition. According to analysts' forecast, Thailand retail sale is projected to grow by $6.10 \%$ in 2021 [5]. The discussed findings and forecasts of analysts show huge growth potential for international retailers like Wal-Mart in the Thai retail industry.

As a next step of the research results, the PESTEL External environment analysis of Thailand Retail Industry is presented in Table 1 below.

Table 1 - External Environment Analysis of Thai Retail Industry

\begin{tabular}{|c|c|c|}
\hline Political & Economic & Social \\
\hline $\begin{array}{l}\text { The Thai government has built } \\
\text { good relationships with other } \\
\text { countries. Although border } \\
\text { tensions have arisen with } \\
\text { Cambodia, Myanmar, and Laos. } \\
\text { But, its relationship with the US } \\
\text { and China are strong. } \\
\text { Corruption can be a threat to } \\
\text { foreign retail investors. As per } \\
\text { transparency international- } \\
\text { corruption index ranking ( } 2018 \text { ), } \\
\text { Thailand took 99th position out } \\
\text { of } 180 \text { countries . } \\
\text { The democratic governmental } \\
\text { structure of Thailand shows } \\
\text { overall political stability. }\end{array}$ & $\begin{array}{l}\text { Thailand scored } 25^{\text {th }} \text { position in the } \\
\text { world's largest economies. } \\
\text { The nominal GDP rate has increased to } \\
\$ 140.2 \text { Billion in the } 4^{\text {th }} \text { Qtr of } 2019 \text { from } \\
\$ 137.8 \text { Billion in the } 3^{\text {rd }} \text { Qtr of } 2019 \text { and } \\
\text { is projected to grow further in the future. } \\
\text { As per the World Bank report (2019), } \\
\text { the rapid shift from lower-income to } \\
\text { the upper-income country has been } \\
\text { observed in Thailand due to economic } \\
\text { development. } \\
\text { The lower unemployment rate was } \\
\text { reported in Thailand at } 0.90 \% \text { in } 2019 \text {. } \\
\text { The growth rate of the Thai economy } \\
\text { has been temporarily slowed down due } \\
\text { to lowering exports and increasing trade } \\
\text { conflicts between the US and China. } \\
\text { Thailand's currency (Baht) volatility can } \\
\text { pose a threat to retail investors like Wal- } \\
\text { Mart. }\end{array}$ & $\begin{array}{l}\text { The total Thai population } \\
\text { has increased by } 0.28 \% \text {, i.e., } \\
\text { from } 69.4 \text { Million (2018) to } \\
69.6 \text { Million (2019), which } \\
\text { is a positive indication of an } \\
\text { increase in domestic demand. } \\
\text { The rapid change in consumers' } \\
\text { behaviour is observed in recent } \\
\text { years as people are now more } \\
\text { likely to spend on luxury } \\
\text { items. } \\
\text { Thai people are mostly seen } \\
\text { as brand-conscious, which can } \\
\text { benefit Wal-Mart due to its } \\
\text { strong brand reputation. }\end{array}$ \\
\hline
\end{tabular}




\section{Continuation of table 1}

\begin{tabular}{|c|c|c|}
\hline Technological & Environmental & Legal \\
\hline $\begin{array}{l}\text { Thailand is moving steadily } \\
\text { towards technological } \\
\text { advancement and is estimated to } \\
\text { increase e-commerce and other } \\
\text { tech-related activities in up- } \\
\text { coming years. } \\
\text { Thai government supports } \\
\text { companies to invest heavily in } \\
\text { technology-infrastructure and } \\
\text { innovation. } \\
\text { The well-developed } \\
\text { infrastructure of Thailand } \\
\text { increases the ease of doing } \\
\text { business. }\end{array}$ & $\begin{array}{l}\text { Attractive environment and weather } \\
\text { conditions are attracting millions of } \\
\text { tourists every year, which shows a } \\
\text { positive indication of high consumer } \\
\text { spending for Wal-Mart. } \\
\text { Thai environmental laws are becoming } \\
\text { strict due to the quick depletion of } \\
\text { resources and growing issues of air, } \\
\text { water pollution, deforestation, and water } \\
\text { scarcity. } \\
\text { Stringent environmental laws are } \\
\text { pressuring companies to adopt } \\
\text { sustainable practices for environmental } \\
\text { protection. }\end{array}$ & $\begin{array}{l}\text { Wal-Mart needs to understand } \\
\text { Thai's strict employment laws } \\
\text { to avoid lawsuits. } \\
\text { In Thailand, disrespecting } \\
\text { Royal Family is considered a } \\
\text { criminal offense. Marketing } \\
\text { and communication strategies } \\
\text { of Wal-Mart must be developed } \\
\text { accordingly. } \\
\text { Strong law enforcement is a } \\
\text { positive indicator, which shows } \\
\text { that if Wal-Mart faces any } \\
\text { harm, then a transparent legal } \\
\text { environment would protect its } \\
\text { rights. }\end{array}$ \\
\hline
\end{tabular}

Based on the PESTEL analysis provided, defining the features of external business environment, it is moving to the next part of the given research, regarding risk identification, risk assessment and risk management plan, respectively.

The successful operations in Thailand require Wal-Mart to firstly conduct a detailed risk assessment and devise mitigation strategies for each identified risk so that it could avoid failure due to some unexpected circumstances.

Thus, in Table 2 below, it is presented the types of risks identified, their description provided, risk intensity assessed, and the risk management strategies proposed those could be implemented, in terms of mitigation possibility.

Table 2 - Risk Assessment and Mitigation Plan

\begin{tabular}{|l|l|l|l|}
\hline \multicolumn{1}{|c|}{ Risk Type } & \multicolumn{1}{|c|}{ Description } & Intensity & \multicolumn{1}{c|}{ Mitigation strategies } \\
\hline Political & $\begin{array}{l}\text { Political instability has raised due } \\
\text { to controversial election results } \\
\text { that were held in March 2019. } \\
\text { Although the Thai legal environment } \\
\text { is strict, it can be perceived that } \\
\text { the Thai judiciary system is } \\
\text { subjected to corruption. On the } \\
\text { basis of Thailand's ranking in the } \\
\text { Transparent International Corruption } \\
\text { Perception Index, it can be assumed } \\
\text { that corruption can disrupt its } \\
\text { economic environment. }\end{array}$ & Moderate & $\begin{array}{l}\text { Political risk cannot be controlled. } \\
\text { However, Wal-Mart can somehow } \\
\text { reduce its effect by increasing its } \\
\text { readiness towards operating in an } \\
\text { uncertain environment and making } \\
\text { a contingency plan to cope with } \\
\text { unexpected situations. }\end{array}$ \\
\hline Economic- Taxation & $\begin{array}{l}\text { The Thai government is likely to } \\
\text { increase the taxation burden that } \\
\text { may affect customer spending. An } \\
\text { increase in corporate tax in the } \\
\text { future can also affect Wal-Mart's } \\
\text { profitability. }\end{array}$ & Low & $\begin{array}{l}\text { Wal-Mart should try to control } \\
\text { this risk by minimizing its costs so } \\
\text { that lower prices could be charged } \\
\text { if consumer spending declines. } \\
\text { Some business practices could be } \\
\text { standardized to avail the economies } \\
\text { of scale. Lower costs will also } \\
\text { reduce the effect of the increase in } \\
\text { corporate taxation. }\end{array}$ \\
\hline
\end{tabular}




\section{Continuation of table 2}

\begin{tabular}{|c|c|c|c|}
\hline $\begin{array}{l}\text { Economic- currency } \\
\text { volatility }\end{array}$ & $\begin{array}{l}\text { Thai's local currency is highly } \\
\text { volatile, which means the exchange } \\
\text { rate lacks stability. It can affect Wal- } \\
\text { Mart's market value and future cash } \\
\text { flows. }\end{array}$ & $\begin{array}{l}\text { Medium } \\
\text { to High }\end{array}$ & $\begin{array}{l}\text { Wal-Mart can mitigate this risk by } \\
\text { conducting a thorough quantitative } \\
\text { analysis of a company's financial } \\
\text { transactions to assess currency risk } \\
\text { exposure and then using different } \\
\text { mitigation tools like natural } \\
\text { hedging. }\end{array}$ \\
\hline Commercial & $\begin{array}{l}\text { Inadaptability to Thai consumer } \\
\text { needs because of ineffective } \\
\text { marketing, promotional and pricing } \\
\text { strategies, and poor selection of } \\
\text { business partners can hamper Wal- } \\
\text { Mart's reputation and international } \\
\text { presence. }\end{array}$ & Moderate & $\begin{array}{l}\text { Wal-Mart can reduce commercial } \\
\text { risk by doing broad-level research } \\
\text { on marketing and pricing strategies } \\
\text { of dominant Thai retail players that } \\
\text { have captured the interest of a huge } \\
\text { audience. }\end{array}$ \\
\hline Expropriation & $\begin{array}{l}\text { Thai's government welcoming and } \\
\text { supportive attitude with strong legal } \\
\text { enforcement minimize the chances } \\
\text { of expropriation risk. However, } \\
\text { corruption in various institutions can } \\
\text { put Wal-Mart's interest in the stake. }\end{array}$ & Low & $\begin{array}{l}\text { Wal-Mart should make sure that } \\
\text { the contractual agreements with the } \\
\text { government while entering the Thai } \\
\text { market are flexible. The contractual } \\
\text { agreements should be developed } \\
\text { in a way to protect the business } \\
\text { interest in the best possible way. }\end{array}$ \\
\hline Legal & $\begin{array}{l}\text { Non-compliance with Thai } \\
\text { legal obligations regarding } \\
\text { employment, labor wages, taxes, } \\
\text { and environmental protection laws } \\
\text { may result in financial penalties and } \\
\text { litigation }\end{array}$ & Moderate & $\begin{array}{l}\text { Wal-Mart must comply with } \\
\text { legal obligations by establishing } \\
\text { policies and procedures that ensure } \\
\text { compliance with country laws } \\
\text { and should adopt environmental } \\
\text { protection practices. }\end{array}$ \\
\hline Culture & $\begin{array}{l}\text { Thailand's culture is distinctive } \\
\text { from that of U.S. Thailand's culture } \\
\text { is collectivist and has high power } \\
\text { distance as compared to the US that } \\
\text { has individualistic and low power } \\
\text { distance culture. }\end{array}$ & High & $\begin{array}{l}\text { Wal-Mart can mitigate this risk } \\
\text { through joint venture with Big C to } \\
\text { gain extensive cultural knowledge } \\
\text { of Thailand (as discussed above). }\end{array}$ \\
\hline Control & $\begin{array}{l}\text { Control risk can be faced in the case } \\
\text { of the joint venture as the company's } \\
\text { operations would not be solely } \\
\text { controlled by Wal-Mart. Conflicts } \\
\text { can arise in a strategic partnership/ } \\
\text { joint venture decision. }\end{array}$ & Moderate & $\begin{array}{l}\text { Wal-Mart can mitigate control risk } \\
\text { by inducing contractual obligations } \\
\text { regarding operations' control in the } \\
\text { joint venture business agreement. } \\
\text { Both partners will be restricted to } \\
\text { follow terms and conditions. }\end{array}$ \\
\hline $\begin{array}{l}\text { Funds Transfer } \\
\text { and currency } \\
\text { inconvertibility }\end{array}$ & $\begin{array}{l}\text { Funds transfer risk can affect Wal- } \\
\text { Mart's ability to convert local } \\
\text { currency into foreign currency and } \\
\text { can disrupt its payment cycle }\end{array}$ & $\begin{array}{l}\text { Medium } \\
\text { to low }\end{array}$ & $\begin{array}{l}\text { Wal-Mart should remain aware } \\
\text { of the government's fund transfer } \\
\text { policies to avoid unnecessary } \\
\text { payment delays. Moreover, it } \\
\text { should avoid getting indulged in } \\
\text { legally suspicious activities that } \\
\text { may put it on the government's } \\
\text { watch list and affect its fund } \\
\text { transfer abilities. }\end{array}$ \\
\hline
\end{tabular}




\section{Discussion}

In addition, in the discussion section, it is interesting to consider possibilities for entry modes within Thai grocery retail industry. Multinational companies consider various entry modes to enter into other countries, which include contractual and investment modes. In the case of Wal-Mart entry in the Thai retail industry, contractual modes are not preferable as they are relatively less profitable as compared to investment modes. Other issues include franchisee/ licensee's lack of international experience and high risk of disloyalty. While investment modes are more profitable and can help in building a strong image in the local market [6]. Amongst investment modes, Wal-Mart is suggested to choose joint-venture as Thailand's institutional and cultural environment is significantly different from the US, due to which Wal-Mart has inadequate knowledge of the local Thai market. Wal-Mart can also face tough competition from local and international retail companies like Tesco Lotus and Big $\mathrm{C}$ that have captured huge market share in the Thai market.

In order to handle this competition and increase local market knowledge, Wal-Mart should make a joint venture with Big $\mathrm{C}$ or any other strong local player. Joint venture mode will allow Wal-Mart to share risks and benefit from its partner's extensive local market knowledge. The combined knowledge of both Wal-Mart and local partners would ultimately boost the synergy effect. A wholly-owned subsidiary is less preferable in the short run due to- high risk, high entry cost, and comprehensive procedure for registration. But, after successfully gaining extensive knowledge and exposure to the Thai market, Wal-Mart can shift to Wholly-owned subsidiary mode.

\section{Conclusion}

The purpose of this paper is to consider how an international business like Wal-Mart can successfully enter into other countries such as Thailand, and what factors should be considered before going to have international engagements. The overall analysis revealed that Wal-Mart is facing tough competition from its competitors worldwide, and to handle this competition, Wal-Mart needs to pursue more internationalization. Wal-Mart should concentrate on the Asian region and choose Thailand for its rapid growth and expansion. It is suggested that Wal-Mart should opt for joint-venture entry mode as it can help in gaining cultural knowledge and get exposure to the local retail market and consumption patterns. External environmental and risk analysis of the Thai retail market showed that Wal-Mart can face several potential risks, which include control, culture, expropriation, legal, political, currency volatility, and currency inconvertibility. It is, therefore, important for Wal-Mart to make effective risk mitigation strategies to successfully operate in the Thai market.

\section{REFERENCES}

1 Reuters. Walmart Inc. WMT.N. [Electronic source]. - 2020. - URL: https://www.reuters.com/companies/ WMT.N (accessed: 7.07.2021)

2 Tyler J. These are the 20 biggest retailers in America. Business Insider. [Electronic source]. - 2020. - URL: https://www.businessinsider.com/biggest-retailers-in-america-based-on-sales-2018-8 (accessed: 7.07.2021)

3 E-Marketer. Total retail sales in the United States from 2012 to 2023 Statista. [Electronic source]. 2020. - URL: https://www-statista-com.lib.pepperdine.edu/statistics/443495/total-us-retail-sales/ (accessed: 7.07.2021)

4 Singh A. What's Hurting Walmart's International Sales? Market Realist. [Electronic source]. - 2019. URL: https://marketrealist.com/2019/02/whats-hurting-walmarts-international-sales/ (accessed: 7.07.2021)

5 Trading Economics. Thailand Retail Sales YoY. [Electronic source]. - 2020. - URL: https:// tradingeconomics.com/thailand/retail-sales-annual (accessed: 7.07.2021)

6 Saxena D. Modes of Entry into International Business: Advantages \& Disadvantages. Super heuristics. [Electronic source]. - 2019. - URL: https://www.superheuristics.com/5-modes-of-entry-into-internationalmarkets/ (accessed: 7.07.2021) 
И.В. ОНЮШЕВА, *1

$\mathrm{PhD}$, қауымдастырылған профессор, AMA, PЖА профессоры.

*e-mail: dr.irina.onyusheva@gmail.com

К. ЛАОЧОКЧАИКУЛ,

MBA.

e-mail: k.laochockchaikul@gmail.com

${ }^{1}$ «Тұран» университеті, Казақстан, Алматы қ.

${ }^{2}$ «Стэмфорд» Халықаралық Университеті, Таиланд, Бангкок қ.

\title{
ШЕТЕЛДІК НАРЫҚҚА ШЫҒУ СТРАТЕГИЯЛАРЫН ТАЛДАУ: «ВОЛ-МАРТТЫН» ТАИЛАНД НАРЫҒЫНА ШЫҒУ МЫСАЛЫНДА
}

\begin{abstract}
Андатпа
Бұл мақала шетелдік нарықтарға шығу стратегиясына, атап айтқанда, көтерме және бөлшек сауда саласындағы әлемдік көшбасшы - американдық «Вол-Март» компаниясының Таиланд нарығына шығуын зерттеу мысалына арналған. Жаһандану жағдайында көптеген фирмалар шетелдік нарықтарға шығу арқылы бизнесін кеңейтуге тырысады, бұл зерттеудің өзектілігін анықтап, көптеген әлеуметтік-экономикалық артықшылықтар әкеледі. Алайда, сонымен қатар, бұл процесс елеулі тәуекелдермен байланысты болғандықтан, бизнесті сәтті іске асыру үшін белгілі бір стратегияларды әзірлеуді талап етеді. Бұл зерттеуде сыртқы бизнес-орта факторларына, сондай-ақ елдің макроэкономикалық ерекшеліктерін, тұтынушылардың өсіп келе жатқан ішкі сұранысы мен сатып алу тенденциясын, сондай-ақ тұтастай алғанда бөлшек сауда секторындағы сатылымның өсуінің оң болжамдарын ескере отырып, «Вол-Март» пен оның Таиланд нарығына шығу шешімі туралы себеп-салдарлық талдау жүргізілді. Сонымен қатар, «Вол-Март» Тайланд нарығына шығу жолдары қарастырылды, тәуекелдерді бағалау жүргізілді және тәуекелдерді басқарудың тиісті стратегиялары жасалды. Халықаралық компаниялар үшін басқа нарықтарға шықпас бұрын сыртқы әлеуметтік-экономикалық орта мен тәуекелдерге терең талдау жүргізу маңызды, өйткені мұндай тәсіл қабылдаушы елдің ерекшеліктері, оның мәдениеті, жергілікті нарық туралы білімі және тұтынушылардың қажеттіліктері, бәсекеге қабілетті бизнесстратегиялар және т.б. туралы толық ақпарат бере алады.
\end{abstract}

Тірек сөздер: халықаралық бизнес, шетелдік нарық, шығу стратегиясы, тәуекелдерді басқару, Вол-Март, Таиланд.

И.В. ОНЮШЕВА, *1 $\mathrm{PhD}$, ассоциированный профессор, профессор PAM, PAE. *e-mail: dr.irina.onyusheva@gmail.com

К. ЛАОЧОКЧАИКУЛ, MBA.

e-mail:k.laochockchaikul@gmail.com

${ }^{1}$ Университет «Туран», Казахстан, г. Алматы ${ }^{2}$ Международный университет «Стэмфорд», Таиланд, г. Бангкок

\section{АНАЛИЗ СТРАТЕГИЙ ВЫХОДА НА ЗАРУБЕЖНЫЙ РЫНОК: НА ПРИМЕРЕ ВЫХОДА «ВОЛ-МАРТ» НА РЫНОК ТАИЛАНДА}

\section{Аннотация}

Данная статья посвящена стратегиям выхода на зарубежные рынки, в частности на примере изучения выхода американской компании «Вол-Март» - мирового лидера в сфере оптовой и розничной торговли - на рынок Таиланда. В условиях глобализации многие фирмы пытаются расширить свой бизнес за счет выхода на зарубежные рынки, что определяет актуальность исследования и приносит множество социально-экономических преимуществ. Однако вместе с тем этот процесс связан с серьезными рисками, что требует разработки определенных стратегий для успешной реализации бизнеса. В данном исследовании проведен анализ факторов внешней бизнес-среды, а также причинно-следственный анализ «Вол-Март» и его решения выйти на рынок Таиланда с учетом макроэкономических особенностей страны, растущего внутреннего спроса потребителей, растущей покупательной тенденции, а также положительных прогнозов роста продаж в розничном секторе в целом. Более того, рассмотрены способы выхода «Вол-Март» на тайский рынок, проведена оценка рисков и разработаны соответствующие стратегии риск-менеджмента. Для международных компаний важно провести углубленный анализ внешней социально-экономической среды и рисков, прежде чем выходить на другие рынки, поскольку такой подход может предоставить исчерпывающую информацию об особенностях принимающей страны, ее культуре, местном рынке и потребностях потребителей, конкурентных бизнес-стратегиях и др.

Ключевые слова: международный бизнес, зарубежный рынок, стратегия выхода, управление рисками, «Вол-Март», Таиланд. 